\title{
ESKATOLOGI DALAM PANDANGAN IBN RUSYD
}

\author{
Mushlihin \\ STFI Sadra Jakarta
}

\begin{abstract}
Abstrak
Satu hal yang pasti didunia ini adalah pertanggungjawaban. Kehidupan akhirat adalah kelanjutan dari berakhirnya kehidupan di dunia. Dalam kehidupan akhirat ini, manusia akan mempertanggungjawabkan atas perbuatannya ketika hidup di dunia. Artikel ini bertujuan untuk memaparkan konstruksi eskatologi Ibn Rusyd. Ibn Rusyd adalah tokoh filsuf Muslim yang mencoba untuk membuktikan bahwa antara hikmah (filsafat) dan syariah itu tidak bertentangan menarik untuk dikaji secara lebih mendalam. Dengan kata lain, dialah filsuf yang secara intens mencoba melakukan integrasi ini, yaitu integrasi antara akal dan wahyu. Ibn Rusyd menyelesaikan permasalahan eskatologinya dengan cara kombinasi antara pemikiran filsafat dan wahyu.
\end{abstract}

Kata Kunci: Eskatologi, Ibn Rusyd

\begin{abstract}
One thing that is certain in this world is accountability. The afterlife is a continuation of the end of life in the world. In this afterlife, man will be responsible for his actions while living in the world. This article aims to describe Ibn Rushd's eschatological construction. Ibn Rushd is a Muslim philosopher who tries to prove that between wisdom (philosophy) and sharia is not an interesting contradiction to be studied in more depth. In other words, he was the philosopher who intensely attempted this integration, the integration of reason and revelation. Ibn Rushd solved his eschatological problems by the way of philosophical thought and divination.
\end{abstract}

Keywords: Eschatology, Ibn Rushd 


\section{PENDAHULUAN}

Permasalahan akhirat adalah permasalahan yang sangat pelik.Itulah sebabnya para filsuf dan dan para teolog beradu argumen tentang masalah ini. Sampai diantara mereka ada yang saling mengkafirkan disebabkan oleh pemahaman yang dianggap keluar dari apa yang diajarkan oleh agama Islam itu sendiri. Benturan yang terjadi diantara para filsuf dan teolog ini menarik untuk dikaji secara mendalam. Teolog-yang menggunakan metode jadal(dialektik) dan bayan (penjelasan) yang juga tidak mengesampingkan aspek burhan (argumentatif)-tidak tinggal diam dalam masalah ini.Juga para filsuf Muslim yang menggunakan metode burhan (argumentatif) yang juga tidak mengesampingkan teks suci sebagai sumber dalam hukum Islam.

Dalam sejarah pemikiran Islam, Ibn Sina yang dikenal dengan syekh alra'is (pemimpin) dan al-farabi yang dikenal dengan muallim al-stani (guru kedua) tidak ketinggalan di dalam membahas permasalahan akhirat ini, atau yang disebut eskatologi, bahkan mereka berdualah yang menggerakkan alGazhali menyusun karyanya Tahafut al-falasifah (Kerancuan para Filsuf).Jika dilihat di dalam karya-karyanya, kita akan melihat Ibn Sina secara khusus membahas masalah akhirat di dalam bukunya al-mabda' wa al-ma'ad (Ibnu Sina, 1323).

Al-Ghazali juga di dalam Tahafut al-Falasifah tidak tinggal diam di dalam permasalahan ini. Karena jika dilihat kedudukan akhirat di dalam Islam di mana ia menjadi bagian di dalam rukun Iman. Sebagai seorang teolog Islam yang dikenal dengan Hujjat al-Islam, al-Ghazali menyerang Ibn Sina dan al-Farabi dalam karyanya tahafut al-falasifah sebagai bentuk pembelaan terhadap agama yang mana al-Ghazali berpandangan bahwa al-Farabi dan Ibn Sina telah melenceng dari pemahaman agama Islam itu sendiri yang disebabkan oleh pengaruh filsafat Yunani. Inilah yang menjadi penyebab alGhazali menulis karya monumentalnya Tahafut Al-Falasifah.

Ibn Rusyd yang hadir setelah al-Ghazali yang mana seorang filsuf paripatetik yang menganut ajaran Aristoteles mengkritik balik al-Ghazali dengan alasan bahwa al-Ghazali tidak memahami filsafat atau salah faham terhadap filsafat (Fakhry) Ibn Rusyd sebagai tokoh filsuf Muslim yang mencoba untuk membuktikan bahwa antara hikmah (filsafat) dan syariah itu 
tidak bertentangan menarik untuk dikaji secara lebih mendalam.Karena dialah filsuf yang secara intens mencoba melakukan integrasi ini, yaitu integrasi antara akal dan wahyu.Dalam penelitian ini, penulis akan membatasi dan memfokuskan penelitian seputar eskatologi Ibn Rusyd. Dari latar belakang masalah, identifikasi, dan pembatasan masalah yang telah dipaparkan diatas, maka rumusan masalah yang dapat diformulasikan adalah sebagai berikut: bagaimana Ibn Rusyd menjelaskan permasalahan eskatologinya. Tujuan dari penelitian ini adalah untuk mengetahui konstruksi eskatologi Ibn Rusyd. Sebagai sumbangan pemikiran dan partisipasi penulis dalam pembangunan ilmu pengetahuan dalam prodi Aqidah dan Filsafat Islamdan juga membuka cakrawala berfikir yang lebih rasional tanpa menghilangkan aspek wahyu.

\section{PEMBAHASAN}

\section{Biografi Pemikiran Ibn Rusyd}

Sebelum membahas pemikiran seorang tokoh, perlu kiranya mengetahui sejarah hidupnya dan latar belakang pemikirannya. Sehingga akan mudah membaca bagaimana konstruksi pemikiran seorag tokoh. Ibn Rusyd lahir di tengah memuncaknya kemajuan dan kekayaan budaya dengan nama lengkap Abu Al-Walid Muhammad Ibn Ahmad Ibn Rushd, pada tahun 1120, yang kemudian di dunia barat dikenal sebagai Averroes. Pada abad ke 12, keluarga Ibn Rushd menjadi aktor dinasti intelektual yang amat terkenal di Cordoba (Guessoum, 2014: 10). Secara berturut-turut, tiga generasinya-termasuk Abu Al-Walid- menjadi hakim agung di kota tersebut.Ini menunjukkan bahwa Ibn Rusyd adalah seorang faqih yang tidak diragukan lagi pemahamannya pada fikih, terutama fikih madzhab Maliki.Ibn Rusyd bahkan memiki karya fikih perbandingan yang berjudul bidayat al-mujtahid, yaitu sebuah karya yang membahas tentang empat madzhab fikih, yaitu fikih Hanafi, Maliki, Syafi'I, dan Hanbali.

Sudah mempelajari tiga bidang utama (agama, hukum, dan kedokteran) kepada guru privat pada masa kanak-kanak. Berbekal dukungan yang kuat dan pikiran yang tajam, ia tampil menonjol dalam berbagai diskusi kelompok, bahkan forum diskusi yang dihadiri orang-orang dewasa. Karena itulah, ketika ia berusia 12 tahun, para guru (termasuk ayahnya) menyadari bahwa 
Abu Al-Walid memiliki 'otak terbaik di Andalusia', sebab ia bisa dengan lihai mendebat para guru dan ulama mengenai masalah-masalah hukum Islam, sains, dan kedokteran. Belakangan, ketika ia dewasa, kredibilitasnya diakui tidak hanya sebagai masterdalam dalam tiga bidang tersebut, tetapi juga karena jasanya meletakkan dasar-dasar teologi dan mengembangkan minat di bidang filsafat serta kebudayaan Yunani dan Islam (Guessoum, 2014: 11)

Ketika ia berusia 27 tahun, Abu Al-Walid bersedia ditunjuk menjadi pengawas sekolah di Marakesh, sebuah kota yang terletak di Maruko yang terkenal sebagai kota yang memiliki budaya dan sistem pembelajaran yang tinggi sekalipun kota tersebut cukup terpencil. Kota tersebut juga banyak terdapat perpustakaan dan toko buku. Untungnya, ketika Abu Al-Walid tinggal di kota tersebut, dibangunlah sebuah masjid kota yang paling terkenal bernama Kutubiyyah (masjid yang memiliki toko buku). Abu Al-Walid tidak menyia-nyiakan kesempatan itu, dan segera mengembangkan kegiatankegiatan intelektual produktifnya di bidang hukum, kedokteran, astronomi, dan filsafat.Ia mulai melakukan pengamatan astronomi, kemudian menulis komentar terhadap Aristoteles, On Heavens. Ia juga menulis kritik terhadap model Ptolomeus dan menggagas digantinya model tersebut dengan teori pergerakan epicyclical dan excentral planet yang berbentul spiral. (salah satu ahli astronomi terbesar di daerah tersebut, Al-Bitruji, juga merupakan murid Ibn Rushd). Dalam film destiny, Chahine menggambarkan bagaimana Ibn Rushd menggunakan teleskop berlensa air dan menyebut bahwa Ibn AlHaytam (pelopor bidang optik) sering merujuk praktik dan teori Ibn Rushd meskipun konsep teleskop berlensa belum ditemukan hingga awal abad ke-17 (Guessoum, 2014: 12)

Pada waktu yang sama, ia juga menulis salah satu buku paling berbobot diantara karya-karya awalnya, yakni kitab Al-Jawami' $\mathrm{Fa}$ Al-Falsafah ("kompendium filsafat") yang memuat beberapa ulasan seputar astronomi (langit dan bumi), fisika, dan metafisika. Karya lain yang juga sangat berpengaruh selama awal karirnya di Marrakish adalah Al-Kulliyyat fi Al-Tibb (komponen ilmu kedokteran). Tak lama kemudian, ia kembali ke Cordoba dan diangkat sebagai hakim di Sevilla. Di kota itu, ia menyaksikan pendirian menara kota Giralda yang sangat terkenal. Semakin terkenal karena pemikiran ensiklopedis dan wawasan intelektualnya yang tajam, Ibn Rushd mulai akrab 
bergaul dengan para pemikir besar ternama di kota itu. Dua filsuf seniornya -Ibn Bajjah (Avempace) dan Ibn Tufayl- memberi pengaruh yang sangat positif pada diri dan karirnya. Konon, kakek Ibn Rushd juga turut campur tangan di hadapan khalifah Al-Murabitun untuk membebaskan Ibn Bajjah ketika ia dipenjara selama periode perburuan kaum fundamentalis (Guessoum, 2014: 13).

Kepada Ibn Rushd yang paling ditonjolkan oleh Ibn Bajjah adalah pandangan Aristoteles. Ibn Bajjah menuntun AbuAl-Walid untuk membaca secara mendalam pandangan-pandangan Aristoteles sehingga ia bisa masuk ke alur pikiran filsuf Yunani tersebut, adapun yang dilakukan oleh Ibn Tufayl terhadap Ibn Rushd adalah lebih pada penalaran secara murni atau bisa dikatakan menekankan kekuatan murni akal. Selain itu, yang dilakukan oleh Ibn Bajjah juga adalah memperkenalkan Abu Al-Walid kepada khalifah Yusuf Ibn 'Abd Al-Mu'min.Dengan sebab perkenalan tersebut terjadilah pertemuan atau hubungan dalam waktu panjang antara Ibn Rushd dan Ibn Bajjah yang keberlansungannya terjadi pasang-surut. Setelah perkenalan itu, Sang Khalifah memerintahkan Ibn Rushd untuk menjelaskan kepadanya karyakarya Aristoteles yang dipandangnya cukup pelik. Dalam itu pula, Ibn Rushd diangkatnya sebagai hakim agama (qadi) di Seville 1169.Pada tahun 1171, Ibn Rushd ditunjuk sebagai kepala Hakim Agama Cordoba, dan pada 1182, ditunjuk sebagai dokter istana Marakesh (Fakhry, 2002: 107).

Abu Yusuf Yáqub yang memiliki panggilan Al-Mansur adalah pengganti dari kedudukan ayahnya pada tahun 1184, dukungan lembaga kekhalifahan pada Ibn Rushd terus berlanjut.Namun, akibat tekanan publik yang menguat, nasib Ibn Rushd kemudian berubah drastis.Mula-mula, Ibn Rushd dibuang ke Lucena, di kepulauan Atlantik, pada 1195. Lalu, buku-bukunya dibakar di depan umum, dan ajaran-ajarannya tentang filsafat dan sains, kecuali kedokteran dan astronomi, dilarang disebarkan (Fakhry, 2002: 108). Untungnya pengasingan Ibn Rushd tidak berlansung lama.Karena khalifah lansung berdamai dengan Ibn Rushd dan memerintahkan Ibn Rushd untuk melanjutkan studi filsafat.Dan sudah barang tentu hal ini membuat Ibn Rushd menjadi riang gembira.

Sumbangan Ibn Rushd pada bidang filsafat, kedokteran, dan teologi sangatlah banyak dan hanya dapat disejajarkan dengan sumbangan Al-Farabi 
dan Ibn Sina, dua tokoh timur yang menyainginya. Meskipun begitu, Ibn Rushd lebih unggul daripada keduanya dalam tiga masalah fundamental, yakni kemahirannya menguraikan dan menafsirkan pemikiran Aristoteles, kontribusinya terhadap bidang yurisprudensi ( $f q h$ ) berupa dua buah karya penting yang salah satunya masih ada hingga kini, dan sumbangannya yang sangat signifikan pada bidang teologi dan kalam (Fakhry, 2002: 108).

Adapun yang menjadi keunggulan dari Ibn Rushd sebenarnya adalah karena ia telah menulis uraian paling ekstensif tentang semua karya Aristoteles kecuali Politics, tidak diterjemahkannya karya tersebut adalah karena ada beberapa alasan aneh sehingga tidak diterjemahkan ke dalam bahasa Arab sampai pada zaman modern. Ibn Rushd telah memberikan komentar dalam tiga versi terhadap karya Aristoteles yang berkenaan dengan Phisycs, Methaphysics, De Anima, De Coelo, dan Analytica Posterior.Tiga versi komentar dari Ibn Rushd tersebut adalah dalam "komentar lengkap", "komentar sedang”, dan "komentar singkat". Di dalam karya-karya tersebut Ibn Rushd sendiri telah melakukan paraphrase terhadap Republic karya Plato. Dan karya yang konon disebut karya terakhir dari Plato ini masih memiliki terjemahan dalam bahasa Ibrani, adapun karya-karya lainnya sudah diterjemahkan ke dalam bahasa Latin dan hanya beberapa jumlah saja yang ada dalam bahasa Arab (Fakhry, 2002: 108).

Tulisan-tulisan Ibn Rushd yang lebih orisinil antara lain adalah adalah Tahafut Al-Tahafut (kerancauan buku "kerancauan" karya AlGhazali), Fasl Al-Maqāl (Pernyataan yang Jelas-Lugas), dan Al-Kashf 'an Manahij Al-Adillah (Uraian tentang Metode-Metode pembuktian). Dalam Tahafut Al-Taha>fut, Ibn Rushd menolak serangan Al-Ghazali , yakni Al-Farabi dan Ibn Sina. Dalam dua karya lainnya, Ibn Rushd menyerang teologi Al-Ash'ari.Isu paling krusial yang dibahas dalam dua karya terakhir adalah ihwal hubungan filsafat dan agama (Fakhry, 2002:108).

\section{Tanggapan terhadap Al-Ghazali Pengetahuan Tuhan Akan}




\section{Partikularitas}

Apa masalahnya dengan gagasan pengetahuan Tuhan atas peristiwa-peristiwa di dunia? Tentu saja, tidak ada masalah dalam membayangkan pengetahuan Tuhan.Namun, falāsifah membatasi pengetahuan ini pada kebenaran-kebenaran abstrak dan niscaya. Bagaimana Tuhan bisa mengetahui tindakan yang saya lakukan sekarang jika Dia tidak memiliki tubuh?Kita mengetahui bahwa Tuhan tidak bertubuh.Karenanya, Dia tidak bisa mengetahui tindakan manusia.Seperti kata Al-Ghazali, pernyataan ini bisa berarti bahwa Tuhan tidak mengetahui Muhammad Saw. Telah menjadi nabi! Kita hanya mempunyai sedikit kesulitan membayangkan pengetahuan Tuhan tentang segala sesuatu, termasuk fakta-fakta temporer dan terbatas, lantaran kita dengan mudah dapat merentangkan ketakterbatasan-Nya pada pengetahuan-Nya (Leaman, 2001: 43).

Pokok masalahnya adalah apakah bagian dari makna "Tuhan" untuk mengetahui semua hal yang partikular dan membangkitkan kita kembali secara fisik?Menurut faläsifah, kelemahan ide Tuhan mengetahui semua fakta adalah bagaimana kiranya menjelaskan Maujud Mahasempurna sampai mengetahui hal yang tidak sempurna. Apakah kemahatahuan berarti mengetahui segala hal? Apakah itu juga berarti mengetahui segala sesuatu termasuk objek-objek yang bersifat remeh-temeh dan sementara?Ataukah kemahatahuan sebetulnya berarti mengetahui prinsip-prinsip umum yang mengatur dunia fana? Menurut Falāsifah, pendapat terakhirlah yang benar. Bagi mereka, tidaklah pantas Tuhan disebut mengetahui segala sesuatu secara mutlak, betapapun remehnya (Leaman, 2001: 43).

Pengetahuan Tuhan tentang objek-objek partikular adalah soal lain yang dijadikan pangkal oleh Al-Ghazali atas para filosof. Ibn Rusyd menjelaskan bahwa para filosof tidak membantah bahwa Tuhan mengetahui keragaman makhluk-makhluk secara partikular. Hanya, bentuk (mode) pengetahuan Tuhan tidak sama dengan bentuk pengetahuan kita. Para filosof umumnya berpendapat bahwa pengetahuan Tuhan adalah sebab bagi keberadaan objek-objek itu.Sebaliknya, pengetahuan kita adalah akibat dari keberadaan 
objek-objek yang diketahui (ma'lum) itu. Dengan perkataan lain, melalui tidak mengetahui itu, Tuhan menciptakan segala sesuatu, sedangkan semua (external objects). Bahkan, lebih dari itu, pengetahuan kita ditentukan oleh keberadaan mereka (Fakhry, 2002: 113).

\section{Eternitas Alam}

kemudian, alam semesta, apakah bersifat kekal-abadi atau sementara, dengan jelas tetap "karya cipta" Tuhan yang, mengingat kemahakuasaan-Nya, mustahil terjadi adanya waktu luang atau interval antara tindakan mencipta dengan kemunculan aktual objek yang terciptakan, yakni alam itu sendiri. Karena itu, demikian Ibn Rusyd berpendapat, mustahil Tuhan menciptakan alam dalam waktu tertentu tanpa Dirinya "terlibat" di dalam waktu tersebut. Jika kemudian kita menelaah kembali proses kejadian alam yang dikemukakan Aristoteles, kaum Neoplatonik, dan "para teolog yang berasal dari tiga agama besar yang ada pada masa kini," akan kita dapati bahwa pandangan yang paling sedikit mengandung keraguan dan lebih sesuai dengan realitas adalah pandangan Aristoteles (Fakhry, 2002: 112). Ini menunjukkan bahwa Ibn Rusyd lebih cenderung menggunakan argumentasi Aristoteles di dalam menjawab permasalahan eternitas alam.

Menurut pandangan itu, "penciptaan" adalah tindakan menggabungkan materi dengan bentuk, atau mengaktualisasikan potensi, dan bukan menciptakan sesuatu dari ketiadaan, yang absurd adanya. Pandangan Aristoteles ini berimplikasi bahwa dalam proses tergabungnya bentuk dengan materi, Tuhan bertindak sebagai Pencipta unsur-unsur dari gabungan itu sendiri, yang tidak lain adalah alam semesta. "Penyusunan" ini bisa saja dianggap berlansung secara terus-menerus atau sekaligus. Bagi Ibn Rusyd, hanya penciptaan yang terus menerus, seperti dikemukakannya dalam tahäfut, yang layak bagi Pencipta sekalian alam. Karena Dialah Yang Mahakuasa lagi Mahakekal-abadi (Fakhry, 2002: 113). 


\section{Kebangkitan Jasmani}

Masalah akhirat memang rada berbeda dengan pengetahuan, namun keduanya sama-sama terkait dengan mukjizat dalam arti apakah Tuhan bisa mengubah hukum-hukum alam.Kita tahu, para filosof meragukan kemungkinannya. Dengan memperluas argumen tentang pengetahuan Tuhan, kita akan tahu mengapa demikian. Hukum-hukum alam bukan sekedar susunan fakta yang acak-acakan.Hukum-hukum tersebut menjabarkan sejumlah prinsip abstrak dan rasional. Dengan prinsip-prinsip tersebut, kita dapat menguraikan apa yang bakal terjadi, siapa kita, dan peristiwa apa yang semestinya terjadi. Sebagai bagian dari hukum alam, kita tahu bahwa kita merupakan bentuk (form) dan materi.Bentuk adalah jiwa, dan materi adalah tubuh. Kita pun tahu bahwa tanpa materi tidak akanada bentuk. Dan apabila tak ada bahan untuk dibentuk, bentuk itu akan menjelmakan dirinya sebagai gagasan dan pengetahuan abstrak (prinsip-prinsip umum) yang tak akan menghasilkan pengetahuan baru (Leaman, 2001: 46). Dan Ibn Rusyd cenderung sejalan dengan pola berfikir ini.

Menurut Ibn Rusyd, kejasmanian (Physicality) kehidupan akhirat ditandaskan untuk mengesankan kepada kebanyakan umat bahwa apa yang kita perbuat di kehidupan ini akan berdampak sampai seterusnya. Akan tetapi, bagi kebanyakan orang, gagasan ini hanya bermakna apabila dikaitkan dengan kepentingan pribadi mereka yang sempit.Karenanya, sudut-pandang (kejasmanian akhirat) ini tidak ada buruknya apabila dapat membantu mereka berbuat baik. Mungkin juga, ia dapat berperan sebagai pendorong pada motivasi moral lebih canggih.

\section{Kehidupan Akhirat.}

Kehidupan akhirat adalah kelanjutan dari berakhirnya kehidupan dunia. Dalam kehidupan akhirat ini, manusia akan mendapatkan konsekuensi logis atas perbuatannya ketika hidup di dunia. Pokok permasalahan yang timbul dalam masalah ini, seperti diasumsikan oleh Ibn Rusyd adalah apakah kehidupan (kenikmatan dan kesengsaraan) di akhirat bersifat jasmani atau rohani atau keduanya? Ada tiga kelompok pandangan dalam masalah terebut: Pertama, Golongan Zindiq, mereka menyakatan bahwa keadaan di akhirat hanya menyangkut masalah kenikmatan dan kelezatan yang tidak terbatas, 
seperti kenikmatan dan kelezatan dalam kehidupan dunia. Kedua, golongan yang menyakatan bahwa keadaan (kenikmatan dan kesengsaraan) di akhirat kelak hanya bersifat rohani.Ketiga, golongan yang menyakatan bahwa keadaan disana adalah bersifat jasmani seperti di kehidupan dunia dengan perbedaan dalam masalah kekelan di akhirat. (Rusyd, 2007: 871-872) Dalam masalah ini, Ibn Rusyd mengambil posisi sependapat dengan golongan yang kedua, karena menurutnya, unsur jasmani (kuantitas/fisik) manusia telah rusak setelah kematian, yang tidak rusak dari manusia setelah kematian adalah unsur rohani (kualitas)nya

\section{PENUTUP}

Ibn Rusyd telah menampilkan dirinya sebagai sosok filsuf yang responsif dan kritis terhadap masalah-masalah keagamaan.Kritik yang dilakukannya didasarkan pada pemahamannya yang mendalam terhadap teks wahyu dan filsafat Aristoteles. Perlu ditegaskan di sini bahwa rasionalitas Ibn Rusyd ternyata tidak menyebabkannya terperangkap dalam hegemoni "liberal" keagamaan, bahkan ia terkesan bersikap "konservatif " dalam memaknai teks-teks wahyu khususnya yang berkaitan dengan konsep ketuhanan. Tak mengherankan, jika ia demikian keras menyatakan kritiknya tentang teori emanasi, wājib al-wujūd dan mumkin al-wujūd, yang ia nilai tidak mempunyai dasar nalar apalagi wahyu.

Ibn Rusyd berpandangan bahwa jiwa yang akan dibangkitkan. Ibn Rusyd menyelesaikan permasalahan eskatologinya dengan cara mengobinasikan antara pemikiran filsafat dan wahyu.

\section{DAFTAR PUSTAKA}

Aminullah el-Hadi, Ibn Rusyd Membela Tuhan (Surabaya: LPAM, 2004)

Ibn Rusyd, Tahafut al-Tahafut, 2007

Ibnu Sina, al-mabda’ wa al-ma’ad, mu’assisaj muthala'at al-islami, Tehran 1323.

Majid Fakhry, Pengantar Filsafat Islam: Sebuah Peta Kronologis

, Sejarah Filsafat Islam: Sebuah Peta Kronologis (Bandung: Mizan, 2002) 
Oliver Leaman, Pengantar Filsafat Islam: Sebuah Pendekatan Tematis, (Bandung: Mizan, 2001)

Ritzer, G \& Goodman, D.J. 2005. Teori Sosilogi Modern. Edisi Keenam. Edisi Terjemahan. Jakarta: Kencana.

Russel, B. 2007. Sejarah Filsafat Barat; Kaitannya dengan Kondisi Sosio-Politik Zaman Kuno hingga Sekarang. Edisi Terjemahan. Yogyakarta: Pustaka Pelajar.

Shahab, H. 2000. Filsafat Wujud dalam Wacana para Filosof Muslim. Jurnal Al Huda. Volume 1. Nomor.1.51-58.

Skousen, M. 2006. Sang Maestro Teori-Teori Ekonomi Modern. Edisi Terjemahan. Jakarta: Prenada.

Sugiyono. 2011. Metode Penelitian Kombinasi (Mixed Methods). Bandung: Alfabeta.

Suriasumantri, J.S. 2007. Filsafat Ilmu: Sebuah Pengantar Populer. Jakarta: Sinar Harapan.

Suyanto, B. 2014. Sosiologi Ekonomi: Kapitalisme dan Konsumsi di Era Masyarakat Post-Modernisme. Jakarta: Kencana.

Thompson, J.B. 2014. Analisis Ideologi Dunia. Edisi Terjemehan. Yogyakarta: IrciSod. 